\title{
Satureja hortensis Bitkisinin Uçucu Yağlarının Hordeum Vulgare L. Tohumları Üzerine Genotoksik Etkileri
}

\author{
Sedat BOZARI ${ }^{1} \quad$ Birsen ÇAKMAK ${ }^{2} \quad$ Havva KURT $^{2}$ \\ ${ }^{1}$ Muş Alparslan Üniv. Eğitim Fak. Matematik ve Fen Bilimleri Eğitimi Böl. Muş \\ ${ }^{2}$ Muş Alparslan Univ. Fen Bilimleri Enstitüsü Muş \\ $\bowtie$ : sedatbozari@gmail.com
}

Geliş (Received): 06.10.2016

Kabul (Accepted): 12.12.2016

\begin{abstract}
ÖZET: Bitkilerin, geçmişten günümüze artan biyoteknolojik yöntemler sayesinde kullanımları oldukça artmıştır. Sahip oldukları sekonder metabolitlerin tıptan tarıma birçok alanda kullanımı hızla yaygınlaşmaktadır. Özellikle kolay metabolize olmaları tarımsal alanlarda sentetik kimyasallar yerine kullanımlarının önünü açmıştır. Tahıl grubundaki bitkilere karşı fitotoksik olmayan dozlarının belirlenmesi güvenli bir şekilde kullanımlarını sağlayacaktır. Bu amaçla; mevcut çalışmada Lamiaceae bitki familyasına ait Satureja hortensis türünün uçucu yağlarının biyolojik aktiviteleri belirlenmeye çalışılmıştır. Türden elde edilen uçucu yağlar, içerik analizleri yapıldıktan sonra Hordeum vulgare L., bitkisinin çimlenen tohumlarına uygulanmış; muhtemel genotoksik etkileri RAPD (Randomly Amplified Polymorphic DNA) PCR ile ölçülmüştür. Dört farklı dozda (0.2, 0.4, 0.8 ve $1.6 \mu \mathrm{L}$ $\mathrm{mL}^{-1}$ ) uygulanan bileşenlerin; $0.4 \mu \mathrm{L} \mathrm{mL}^{-1}$ dozunda genomik stabiliteyi $\% 46.16$ 'ya düşürdüğü diğer dozlarda ise \% 50'nin üzerinde tuttuğu gözlenmiştir. Ayrıca uçucu yağların; tüm dozlarda çimlenen arpa tohumlarının kök uzunluklarını kontrole göre arttırdığı, gövde uzunluklarında ise kontrole göre önemli sayılabilecek inhibisyonlara neden olduğu belirlenmiştir. Sonuç olarak bitki bileşenlerinin literatürde geçen sentetik kimyasalların gösterdiği etkiye benzer aktivite gösterdikleri belirlenmiştir. Hordeum vulgare L. tohumlarında fitotoksik sayılabilecek $0.4 \mu \mathrm{L}$ $\mathrm{mL}^{-1}$ dozu dışındaki diğer dozların yabancı bitkilere karşı biyopestisit olarak kullanılabilme potansiyeli ortaya çıkmıştır.
\end{abstract}

Anahtar Sözcükler: Biyopestisit, Allelopati, Esansiyel Yağlar, GTS

\section{Genotoxic Effects of the Essential Oil Obtained from Satureja hortensis Against to Hordeum Vulgare L. Seedlings}

\begin{abstract}
Plants use in many fields has increased significantly with the increasing of biotechnological methods from past to present. Their secondary metabolites are commonly used in many fields from medicine to agriculture. Because of their easy degradation, they will be used as an alternative to the synthetic chemicals. Deciding their proper non-phytotoxic doses for cereals will secure their safe usage. The present study aimed to determine the potential biopesticide activity of plants natural components in weeds. Thus, the essential oils obtained from Satureja hortensis species of Lamiaceae family were subjected to analysis of volatiles and applied to Hordeum vulgare $\mathrm{L}$. seedlings. Potential genotoxic effects of these components on the seedlings were determined by RAPD (Randomly Amplified Polymorphic DNA) PCR. The oils were applied in four different doses $\left(0.2,0.4,0.8\right.$ and $\left.1.6 \mu \mathrm{L} \mathrm{mL}^{-1}\right)$. Results indicated that the third $\left(0.4 \mu \mathrm{L} \mathrm{mL}^{-1}\right)$ dose has changed the genomic stability about $46.16 \%$ and remaining doses changed the genomic stability over the $50 \%$. The effects of the essential oils on root and stem length of barley seedlings were varied. The oils have increased the root length and inhibited stem length in all doses compared to the control. It was concluded that plant essential oil components showed similar effects of synthetic chemicals in the literature. With the exception of the $0.4 \mu \mathrm{L} \mathrm{mL}^{-1}$, which may be phytotoxic in Hordeum vulgare $\mathrm{L}$. seeds, all doses tested in the study have the potential to be used as bio pesticides against weeds.
\end{abstract}

Keywords: Biopesticide, Allelopathy, Essential Oils, GTS

\section{GíRis}

Yeryüzünde farklı bölgelere yayılan birbirleriyle ve çevreleriyle sürekli etkileşim içinde olan bitkiler, dünya üzerindeki doğal ekosistemleri oluşturmaktadır. Geniş yayılış alanları ve biokütleleriyle besin zincirinin temel basamağının vazgeçilmez elemanlarını oluşturan bitkilerin doğadaki yayılışları biyotik (aynı türe ya da farklı türlere ait bitkiler, hayvanlar, mantarlar ve bakteriler) ve abiyotik (sıcaklık, güneş ışınları, toprak içeriği, su ve topografya) faktörler tarafindan belirlenmektedir (Bozarı, 2012). Farklı fitocoğrafik alanlara adapte olan bitkiler özellikle endojen ve ekzojen kaynaklı saldırılara karşı koyabilmek için farklı metabolitler üretmişlerdir.

Sekonder metabolit olarak bilinen ve sayıları yüz binlere ulaşmış azot içeren (alkaloidler, aminler, siyanojenik glikozitler, alkamidler, peptitler, serbest amino asitler ve glikosinolatlar) ve içermeyen (terpenler, poliketidler, fenolik bileşikler, saponinler ve poliasetilenler) bu bileşikler; bitkinin farklı doku ya da organlarında sentezlenebilirler (Facchini, 2001). Bitkinin kuru ağırlığının \% 1-3'ünü oluşturan bu metabolitlerden hidrofilik olanlar hücrede kofullarda depolanırken, lipofilik olanlar ise; reçine kanallarında, 
latisiferlerde, tüylerde, yağ hücrelerinde veya kütikül tabakasında depo edilirler (Wink, 2010). Hücre içinden ziyade, epidermal sistemlere yakın yerlerde depo edildikleri için geçmişte sekonder metabolitlerin atık ve fonksiyonel olmayan maddeler olduğu hakkında görüşler ileri sürülmüştür (Hartmann, 2007). Ancak bu görüşlerin doğru olmadığı birçok çalışmayla ortaya çıkmıştır. Söz konusu bitkisel metabolitlerin geçmişten günümüze farklı alanlarda kullanıldığı bilinmektedir. Uçucu karakterdeki, az miktarlarda bile oldukça keskin bir kokuya sahip uçucu yağlar, bu bileşikleri çokça içerirler. Farklı canlılara karşı allelopatik etkiden (Kobayashi ve ark., 2008; Mutlu ve Atici, 2009) antioksidan etkiye (Gkinis ve ark., 2010; Gulluce ve ark., 2007), antibakteriyel özelliklerden (Gulluce ve ark., 2007; Shafaghat, 2011), nematod öldürücü (Ntalli ve ark., 2010) ve kovucu (Kim ve ark., 2010) etkiye kadar birçok biyolojik aktivite sergiledikleri önceki çalışmalarda belirtilmiştir.

Yeryüzünde tanımlanmış dört yüz bin bitki türü içinde 200 cins ve 3200 tür ile ifade edilen Lamiaceae familyası monoterpen, diterpen ve seskiterpenler açısından zengin aromatik metabolitler taşıyan bir familyadır. Familyaya ait türler tıp, eczacılık, parfümeri gibi sanayilerin yanı sıra, gida olarak da tüketilebilmektedir (Bozari ve ark., 2013). Bu familyanın farklı türleriyle yapılan çalışmalarda türlerin çoğunun tohum çimlenmesini, büyüme ve gelişmeyi etkilemek koşuluyla allelopatik etkiye neden oldukları belirlenmiştir (Basile ve ark., 2011).

Örneğin; ülkemizde Ege Bölgesinde nadir olmakla birlikte birçok şehrimizde doğal olarak yetişen ve Sater de denilen Satureja hortensis bu familyaya ait olup uçucu yağ içeriği bakımından oldukça zengindir. Bitkiden elde edilen drogların gaz giderici, terletici, iştah açıcı, idrar artırıcı, uyarıcı ve cinsel gücü artırıcı özelliklere sahip oldukları bilinmektedir (Katar ve ark., 2011). Türün aynı zamanda antimikrobiyal (Güllüce ve ark., 2003; Şahin ve ark., 2003), antienflamatuar (Hajhashemi ve ark., 2002) ve antifungal olduğu da bilinmektedir. Türün mısır tohumları üzerine toksik etki gösterdiği, kök ve gövde gelişimin engellediği bilinmektedir (Bozar1, 2012). Satureja hortensis'den elde edilen uçucu yağlar, Tetranychus urticae Koch ve Bemisia tabaci Genn. olarak bilinen böceklerin kontrolünde de kullanılabilmektedir (Aslan ve ark., 2004). Tworkoski (2009) bu türden elde edilen uçucu yağların herbisidal aktivitesinin olabileceğini vurgulamıştır. Öte yandan türden elde edilen uçucu yağların muhtemel insektisidal potansiyelinin Tribolium castaneum üzerinde denendiği bir çalışmada ise uçucu yağların artan dozuyla beraber vitalitenin düştüğü tespit edilmiştir (Maede ve ark., 2013).

Yapılan çalışmalardan da anlaşılacağı gibi türün biyolojik mücadelede etkin olarak kullanıldığını söylemek mümkündür. Öte yandan özellikle tarımsal arazilerde kullanılan sentetik kimyasalların olumsuz etkilerine de oldukça sık rastlanmaktadır (Cenkci ve ark., 2009; Aksakal ve ark., 2013; Bozari ve Aksakal, 2013). Bu maddelerin besin piramidinde birikmeleri; bitkisel beslenen canlılarda yığılmalara; dolayısıyla sağlık sorunlarıyla karşı karşıya kalmalarına neden olacaktır. Sentetik kimyasallar yerine benzer aktivite gösteren ancak yıkımları daha kolay olan doğal bileşenlere yönelmek söz konusu sıkıntıları nispeten ortadan kaldıracaktır.

Biyopestisit olarak bilinen hayvanlar, bitkiler, bakteriler ve çeşitli mineraller şeklinde özetlenebilecek birçok doğal maddeden elde edilen pestisit çeşitlerinin bazı avantajları söz konusudur. Geleneksel pestisitlere göre daha az zararlı bileşiklerdir. Bunlar doğrudan hedef zararlıyı ve yakın benzerliği olan canlıları etkilerlerken; geleneksel pestisitler kuşlar, böcekler ve memelileri de kapsayacak şekilde daha geniş bir grubu etkiler (Yarsan ve ark.).

$\mathrm{Bu}$ özelliklerden yola çıkılarak mevcut çalışmada, Satureja hortensis türünden elde edilen uçucu yağların biyoherbisit olarak kullanılabilmeleri için ön çalışmalar yürütülmüştür. Tahıl grubundan Hordeum vulgare L.'ye karşı fitotoksik olmayan dozların belirlenmesi bu dozların yabancı bitkilere karşı denenebileceğini göstermiştir.

\section{MATERYAL ve YÖNTEM \\ Bitki Örneği}

Satureja hortensis bitkisi Haziran-Temmuz 2014 yılında Bingöl ilinden toplanıp güneş görmeyen gölgelik alanda kurutulmuştur. Çimlenme deneylerimde kullanılacak olan arpa (Hordeum vulgare L.) (Tarm 92) Ankara Üniversitesi Ziraat Fakültesinden temin edilmiştir.

\section{Uçucu yağların eldesi}

Gölgede kurutulan bitkinin kök gövde ve yaprak kısımları parçalayıcıda (Waring Germany Cb-15t) toz haline getirilmiştir. Clevenger aparatı hidrodistilasyon yöntemi ile 3 saat kaynatılmıştır. Yaklaşık 100 gramlık örnekte tek kaynatmada $0.8 \mathrm{~mL}$ kadar uçucu yağ elde edilmiştir Elde edilen yağlar kullanılacağı güne kadar $+4^{\circ} \mathrm{C}$ de muhafiza edilmiştir. Elde edilen uçucu yağların içeriği Ağrı İbrahim Çeçen Üniversitesi Merkezi Araştırma Laboratuvarı tarafindan GC-MS (Gas chromatography-mass spectrometry) cihazı kullanılarak belirlenmiştir.

\section{GC-MS (Gas chromatography-mass spectrometry) analizi}

Elde edilen uçucu yağların içeriğinin belirlenmesi için SGE-BPX5 MS (30 m X 0.25 mm i.d., $0.25 \mu \mathrm{m})$ kapiller kolona sahip Thermofinnigan Trace GC/Trace DSQ/A1300, (E.I Quadrapole) cihazı kullanılmıştır. GC-MS ölçümleri için iyonizasyon enerjisi $70 \mathrm{eV}$ olan elektron iyonizasyon sistemi kullanılmıştır. Taşıyıcı gaz olarak Helyum gazı kullanılıp akış oranı $1 \mathrm{~mL} \mathrm{dk}{ }^{-1}$ olarak ayarlanmıştır. Enjektör sıcaklığı $220{ }^{\circ} \mathrm{C}$ olarak belirlenirken, MS transfer hattı sicaklığ $1290{ }^{\circ} \mathrm{C}$ olarak ayarlanmıştır. Program 50-150 ${ }^{\circ} \mathrm{C}$ sicaklıklarında $3{ }^{\circ} \mathrm{C}$ $\mathrm{dk}^{-1}$ hızla başlatılıp $1 / 100 \mathrm{v} \mathrm{v}^{-1}$, oranında Asetonitril ile dilüe edilen örneklerden $1 \mu \mathrm{L}$ manuel olarak cihaza enjekte edilmiş ve cihaz ayırma moduna alınmıştır. 
Bileşenler, tutunma zamanlarının (RT) birbirine yakınlığı ve kütle spektrumları göz önüne alınarak Wiley $7 \mathrm{~N}$ Library Data of the GC-MS System ve literatürle karşılaştırılarak tanımlanmıştır.

\section{Çimlenme deneyleri}

Arpa tohumlarının yüzeysel sterilizasyonu, tohumların \% 5'lik Sodyum hipoklorit (NaOCl)'de 10 $\mathrm{dk}$ bekletildikten sonra en az $5 \mathrm{kez}$ saf suyla yıkanmasıyla sağlanmıştır. Eşit büyüklükteki tohumlar seçilerek in vitro ekimleri yapılmıştır. Uçucu yağlar farklı dozlarda $\left(0.2,0.40 .8\right.$ ve $\left.1.6 \mu \mathrm{L} \mathrm{mL}^{-1}\right)$ Tween 20 içerisinde çözülerek sulama çözeltilerine eklenmiş kontrol için sadece Tween 20 içeren saf su kullanılmıştır. Örnekler daha sonra etüvde gelişmeye bırakılıp 7. günün sonunda gök ve gövde örnekleri ayrı ayrı alınarak uzunlukları ölçülüp etiketlenmiştir. Örnekler çalışmanın yapılacağı zamana kadar $-20{ }^{\circ} \mathrm{C}$ 'de bekletilmiş deneyler üç tekerrürlü olarak gerçekleştirilmiştir.

\section{DNA izolasyonu ve RAPD-PCR protokolï}

Örnekler sıvı azotta öğ̈̈tülerek toz haline getirilip DNA izolasyonları gerçekleştirilmiştir. DNA izolasyonu, Vivantis marka GF-1 Nucleic Acid Extraction Kits kullanılarak üretici firmanın uygulama yönergesinde önerdiği şekilde yapılmıştır. RAPD -PCR için Çizelge 1'deki primerler kullanılmıştır.

Çizelge 1. RAPD'de kullanılan primerler ve DNA sekans bilgileri

\begin{tabular}{cccc}
\hline No & Primer & & Primer sekansı \\
\hline $\mathbf{1}$ & OPB-1 & $5^{\prime} \rightarrow 3^{\prime}$ & GTTTCGCTCC \\
$\mathbf{2}$ & OPB-4 & $5^{\prime} \rightarrow 3^{\prime}$ & GGACTGGAGT \\
$\mathbf{3}$ & OPB-5 & $5^{\prime} \rightarrow 3^{\prime}$ & TGCGCCCTTC \\
$\mathbf{4}$ & OPB-6 & $5^{\prime} \rightarrow 3^{\prime}$ & TGCTCTGCCC \\
$\mathbf{5}$ & OPB-7 & $5^{\prime} \rightarrow 3^{\prime}$ & GGTGACGCAG \\
$\mathbf{6}$ & OPB-8 & $5^{\prime} \rightarrow 3^{\prime}$ & GTCCACACGG \\
$\mathbf{7}$ & OPB-12 & $5^{\prime} \rightarrow 3^{\prime}$ & CCTTGACGCA \\
$\mathbf{8}$ & OPB-13 & $5^{\prime} \rightarrow 3^{\prime}$ & TTCCCCCGCT \\
\hline
\end{tabular}

PCR işlemi için şu protokol izlenmiştir. Önceden otoklavlanmış $0.5 \mathrm{~mL}$ 'lik PCR tüpüne $3 \mu \mathrm{L} 10 \mathrm{x}$ PCR tamponu, (10 mg mL $\left.\mathrm{m}^{-1}\right), 1.2 \mu \mathrm{L}$ dNTP $(10 \mathrm{mM}), 1.2 \mu \mathrm{L}$ $\mathrm{MgCl}_{2}(25 \mathrm{mM}), 3 \mu \mathrm{L}$ DNA (100 ng $\left.\mu \mathrm{L}^{-1}\right), 1.2 \mu \mathrm{L}$ primer $(25 \mathrm{pmol}), 0.4 \mu \mathrm{L} 5$ Unit $\mu \mathrm{L}^{-1}$ Taq DNA polimeraz konulmuştur. Saf su ilave edilerek hacim 30 $\mu$ L'ye tamamlanmış (Agar ve ark., 2010) PCR döngüleri Cenkçi vd. (2009)'ne göre oluşturulmuştur. $94{ }^{\circ} \mathrm{C}$ 'de 4 dakika denatüre edilen örnekler daha sonra 40 döngü olacak şekilde her bir döngü için; $94{ }^{\circ} \mathrm{C}$ 'de 45 saniye $36{ }^{\circ} \mathrm{C}$ 'de 45 saniye ve $72{ }^{\circ} \mathrm{C}$ 'de 60 saniye olacak şekilde düzenlenmiştir. Daha sonra $72{ }^{\circ} \mathrm{C}$ 'de 8 dakika süren 1 döngü sonunda örnekler $+4^{\circ} \mathrm{C}^{\prime}$ ye kaldırılmıştır. PCR işleminden sonra örnekler önceden hazırlanan \%1'lik agaroz jele yüklenerek $1 \mathrm{X}$ TBE (Tris Borat Edta) tamponunda yürütülmüştür.

\section{RAPD analizleri ve genomik kalpp sabitliliğinin (Genomik template stability (GTS) belirlenmesi}

Her bir primer için tüm örneklerde amplifiye olan DNA bantlarının varlığı ve yokluğu, negatif kontrol RAPD profillerine göre bant yoğunluklarındaki azalma ve artmalar agaroz jel görüntüleme cihazı ve Total LAB TL 120 (Nonlinear Dynamics) yazılımıla belirlenmiştir. Genomik kalıp sabitliliği (\%) tüm primer ürünleri için;

$$
100 *\left(1-\frac{a}{n}\right)
$$

formülünden yararlanılarak hesaplanmıştır. Formüldeki $a$ her bir uygulama örneği için tespit edilen RAPD polimorfik profillerini, $n$ ise ilgili primerle negatif kontrol grubunda elde edilen DNA toplam band sayıs1 olarak seçilmiştir. Uygulama gruplarına ait RAPD profillerinde gözlenen polimorfizm negatif kontrol grubuna göre yeni bir bandın ortaya çıkması veya mevcut bir bandın kaybolmasını kapsadı. Her bir parametrenin (GTS) hassaslığını karşılaştırmak için, bu parametrelerdeki değişimler kontrollerine (\% 100'e sabitlenecek) göre yüzde değişim olarak hesaplanmıştır (Cenkci ve ark., 2009).

\section{İstatistiksel Analiz}

Çimlenme oranlarından elde edilen verilerin istatistik analizleri SPSS v. 16.0 paket programı kullanılarak (one way ANOVA) yapılmıştır. Veri ortalamaları arasındaki önemli düzeydeki $(\mathrm{P}<0.05)$ farklılıklar ise Duncan çoklu karşılaştırma testi ile belirlenmiştir.

\section{BULGULAR}

Satureja hortensis'ten elde edilen uçucu yağların içeriği GC-MS yöntemiyle analiz edilip uçucu yağların \% 97.52'si tespit edilmiştir (Çizelge 2). Toplam 38 bileşenden en fazla bulunanlar sırasıyla; \% 15.36 oranıyla Siklohegzan, \% 14.69 oranıyla, Karvakrol, \% 13.03 oranıyla Simen, \% 11.86 oraniyla Fenol ve \% 10.61 oranıyla Timol olduğu gözlenmiştir (Çizelge 2). Toplam içeriğin \% 2.48'ini oluşturan 103 içeriğin ismi tespit edilememiştir.

\section{Uçucu yağların çimlenme oranları üzerine etkisi}

Satureja hortensis'ten elde edilen uçucu yağların dört farklı dozda uygulandığı Hordeum vulgare tohumlarının çimlenme oranları Çizelge 3'te gösterilmiştir.

Elde edilen uçucu yağların Hordeum vulgare tohumlarının kök gelişimini tüm dozlarda olumlu yönde etkilediği $1.6 \mu \mathrm{L} \mathrm{mL} \mathrm{m}^{-1}$ dozunda bu etkinin en yüksek olduğu belirlenmiştir. Gövde uzunluklarının ise kök ve kontrole göre oldukça düştüğü ve bu oranın istatistiksel olarak önemli olduğu belirlenmiştir. 
Çizelge 2. Satureja hortensis'in uçucu yağ bileşenleri

\begin{tabular}{|c|c|c|c|}
\hline No & TS & İçeriğin Adı & (\%) Oranı \\
\hline 1 & 2.587 & Naftil Asetamit & 0.22 \\
\hline 2 & 2.855 & Borneol L & 0.17 \\
\hline 3 & 2.982 & Terpineol & 0.19 \\
\hline 4 & 3.184 & 3-Siklohegzan & 0.06 \\
\hline 5 & 4.291 & Timol & 10.61 \\
\hline 6 & 4.433 & Fenol - 2-Metil & 11,86 \\
\hline 7 & 4.552 & Bifenil & 0.64 \\
\hline 8 & 4.958 & Fenol-5Metil Asetat & 0.5 \\
\hline 9 & 5.130 & Karvakril asetat & 0.49 \\
\hline 10 & 5.520 & Omethoat & 0.11 \\
\hline 11 & 5.589 & Metilfenoksi asetik asit & 0.11 \\
\hline 12 & 5.853 & Karyofilen & 0.09 \\
\hline 13 & 6.005 & Aromadendren & 0.03 \\
\hline 14 & 6.126 & Jasmolin II & 0.53 \\
\hline 15 & 6.229 & Pyretrin I & 0.04 \\
\hline 16 & 6.424 & Sinerin II & 0.62 \\
\hline 17 & 6.544 & Pyretrin II & 1.19 \\
\hline 18 & 6.653 & Kaptafol & 0.05 \\
\hline 19 & 7.325 & Karyofilen Oksid & 0.54 \\
\hline 20 & 7.557 & Alletrin & 0.07 \\
\hline 21 & 9.347 & Limonen & 3.82 \\
\hline 22 & 9.610 & Beta-Pinene & 2.98 \\
\hline 23 & 9.822 & Simen & 13.03 \\
\hline 24 & 9.973 & Gamma Terpinen & 9.19 \\
\hline 25 & 10.118 & Izoprokarb & 0.32 \\
\hline 26 & 10.197 & Trans-Sabinen Hidrat & 0.25 \\
\hline 27 & 10.540 & Cinmetilin & 1.81 \\
\hline 28 & 10.888 & Karvakrol & 14.69 \\
\hline 29 & 10.941 & Siklohegzonen & 15.36 \\
\hline 30 & 11.105 & Fenol Asetat & 1.63 \\
\hline 31 & 11.168 & Karvakril Asetat & 1.27 \\
\hline 32 & 11.386 & Jasmolin I & 0.14 \\
\hline 33 & 11.526 & Trans Karyofillen & 1.63 \\
\hline 34 & 11.666 & Beta Bisabolen & 0.89 \\
\hline 35 & 11.772 & Leden & 0.61 \\
\hline 36 & 12.152 & (-)Karyofilen Oksid & 1.65 \\
\hline 37 & 12.768 & Pirohidrojasmon-1 & 0.1 \\
\hline 38 & 13.898 & Promekarb & 0.03 \\
\hline
\end{tabular}

TS:Tutunma süresi

Çizelge 3. Satureja hortensis bitkisinden elde edilen uçucu yağların uygulandığı Hordeum vulgare tohumlarının kök ve gövde uzunlukları

\begin{tabular}{ccc|}
\hline Uygulanan dozlar & \multicolumn{2}{c|}{ Hordeum vulgare } \\
Kök (cm) & Gövde (cm) \\
$\mathbf{0 . 2} \boldsymbol{\mu L ~ \mathbf { ~ m } ^ { - 1 }}$ & $10.250 \pm 1.030^{\mathrm{c}}$ & $2.625 \pm 1.143^{\mathrm{a}}$ \\
$\mathbf{0 . 4} \boldsymbol{\mu L ~ \mathbf { ~ m } ^ { - 1 }}$ & $10.250 \pm 1.689^{\mathrm{c}}$ & $5.250 \pm 0.829^{\mathrm{c}}$ \\
$\mathbf{0 . 8} \boldsymbol{\mu L ~ \mathbf { ~ m L } ^ { - 1 }}$ & $9.750 \pm 0.924^{\mathrm{b}}$ & $5.000 \pm 1.541^{\mathrm{c}}$ \\
$\mathbf{1 . 6} \boldsymbol{\mu L ~ \mathbf { ~ m L } ^ { - 1 }}$ & $11.750 \pm 1.436^{\mathrm{d}}$ & $3,750 \pm 1.163^{\mathrm{b}}$ \\
Kontrol & $5.625 \pm 2.258^{\mathrm{a}}$ & $7.250 \pm 1.701^{\mathrm{d}}$ \\
\hline
\end{tabular}

Duncan's multiple range testine göre $\mathrm{P} \leq 0.05$ seviyesinde önemli

* Aynı kolondaki aynı harfle ifade edilmiş örnekler arasında önemli fark yoktur $(\mathrm{P}<0.05)$

\section{Rapd analizleri}

Çimlenen arpa tohumlarının 8 farklı oligonükleotid primerine (Çizelge 1) karşı gösterdikleri benzerlik ve farklılıklar (Çizelge 4) elde edilen agaroz jel görüntülerinin Total LAB TL v.120 programında değerlendirilmesiyle belirlenmiştir. Yeni oluşan ve kaybolan bantlarla beraber genomik kalıp stabilitesi (GTS) ölçülmüştür.

Hordeum vulgare L.'ye yapılan uygulama sonucunda oluşan bantlar Çizelge 4'te sunulmuştur. Polimorfizm oranlarının dozdan bağımsız bir şekilde değiştiği gözlenip en fazla polimorfik banda $0.8 \mu \mathrm{L} \mathrm{mL}^{-}$ 1 dozunda rastlanırken en düşük oran $0,2 \mu \mathrm{L} \mathrm{mL}^{-}$ ${ }^{1}$ dozunda ölçülmüştür. Bant profillerinde ise yoğunluk değişimi gözlenmiştir (Şekil 1).

\section{TARTIŞMA ve SONUÇ}

Günümüzde yabancı otlarla mücadelede ekim nöbetlerinden (Liebman ve Dyck, 1993) allelopatik etkileşimlere (Singh ve ark., 2003) herbisit kullanımından (Currie ve Geier, 2016) yakma yöntemlerine (Güney ve ark., 2016) kadar farklı yöntemlerin kullanıldığ 1 bilinmektedir. $\mathrm{Bu}$ yöntemlerin çoğunun ekosistemi olumsuz etkilediği biyoçeşitliliğe zarar verdiği rapor edilmiştir (Tokatlı ve ark., 2016). Hızla artan dünya nüfusuna yeterli besin üretebilmek için gösterilen bu çaba, özellikle sentetik kimyasalların kullanımı ile uzun vadede canlılık üzerinde olumsuz etkiler bırakacaktır. Literatürde bunun örneklerine rastlamak mümkündür. Örneğin; Chlorpyrifos ethyl ve Fenobucarb etken maddeleri ile yapılan çalışmada hedef olmayan organizmalar üzerine negatif etkilerinin olduğu (Nguyen ve ark., 2016) atrazin herbisidi ve chlorpyrifos, lambda-cyhalothrin ile imidacloprid insektisitlerinin uygulandığ1 toprak solucanlarında toksik etkiye neden oldukları (Wang ve ark., 2016) belirlenmiştir. Yine söz konusu maddelerin doğada birikmeleriyle toksik doza ulaşabilecekleri yapılan çalışmalarla ortaya konmuştur (Milun ve ark., 2016; Sahai, 2016).

Oysa yakın geçmişte biyolojik mücadele için allelopati, biyolojik rekabet gibi yaklaşımlar üzerinde durulmuş ve sentetik kimyasallara benzer aktivite gösteren doğal biyolojik ajanlar elde edilmiştir (Sodaeizadeh ve Hosseini, 2012; Nicot ve ark., 2016). Özellikle bitki bileşenlerinin yüksek aktiviteye sahip oldukları yapılan çalışmalarla sabittir (Villaverde ve ark., 2016; Mossa, 2016; Gormez ve ark., 2016).

Söz konusu doğal bileşenlerin hedef olmayan organizmalara etkilerinin belirlenmesi kullanımları açısından önem arz etmektedir. Mevcut çalışmada da yüksek biyolojik aktiviteye sahip Satureja hortensis uçucu yağlarının arpa tohumları üzerine biyolojik aktiviteleri incelenerek olası biopestisit olarak kullanılabilmeleri için önemli veriler elde edilmiştir. 
Çizelge 4. S. hortensis'ten elde edilen uçucu yağların uygulandığı Hordeum vulgare L. tohumlarının RAPD profilleri

\begin{tabular}{|c|c|c|c|c|c|c|c|}
\hline \multirow[t]{2}{*}{ No } & \multirow[t]{2}{*}{ Primer Adı } & \multirow[b]{2}{*}{ Kontrol } & & \multicolumn{4}{|c|}{ Hordeum vulgare $L$. } \\
\hline & & & & $0.2 \mu \mathrm{L} \mathrm{mL}^{-1}$ & $0.4 \mu \mathrm{L} \mathrm{mL}^{-1}$ & $0.8 \mu \mathrm{L} \mathrm{mL}^{-1}$ & $1.6 \mu \mathrm{L} \mathrm{mL^{-1 }}$ \\
\hline \multirow[t]{2}{*}{1} & OPB-1 & 3 & + & ND & ND & ND & ND \\
\hline & & & - & ND & 549 & 549 & 549 \\
\hline \multirow[t]{2}{*}{2} & OPB-4 & 6 & + & ND & ND & ND & ND \\
\hline & & & - & ND & 940,759 & 940,759 & $940,759,679$ \\
\hline \multirow[t]{2}{*}{3} & OPB-5 & 4 & + & 636,270 & 636,270 & 725,270 & 270 \\
\hline & & & - & ND & ND & 800 & ND \\
\hline \multirow[t]{2}{*}{4} & OPB-6 & 5 & + & ND & ND & ND & ND \\
\hline & & & . & 700 & 700,575 & 700,575 & 700,575 \\
\hline \multirow[t]{2}{*}{5} & OPB-7 & 2 & + & ND & ND & ND & ND \\
\hline & & & 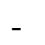 & ND & ND & ND & ND \\
\hline \multirow[t]{2}{*}{6} & OPB-8 & 3 & + & 974,157 & ND & ND & ND \\
\hline & & & - & ND & 500,385 & 500,385 & 500,385 \\
\hline \multirow[t]{2}{*}{7} & OPB-12 & 2 & + & 186 & 244 & 203 & 203 \\
\hline & & & - & ND & ND & 391 & 391,328 \\
\hline \multirow[t]{5}{*}{8} & OPB-13 & 1 & + & ND & ND & 515 & 515 \\
\hline & & & 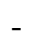 & ND & ND & 609 & ND \\
\hline & Toplam bant & 26 & & 6 & 10 & 14 & 13 \\
\hline & Polimorfizı & & & 23.07 & 38.46 & 53.84 & 50 \\
\hline & GTS or & & & 72.93 & 61.54 & 46.16 & 50 \\
\hline
\end{tabular}

ND: Belirlenmedi, -:Kaybolan bantlar, +:Oluşan bantlar

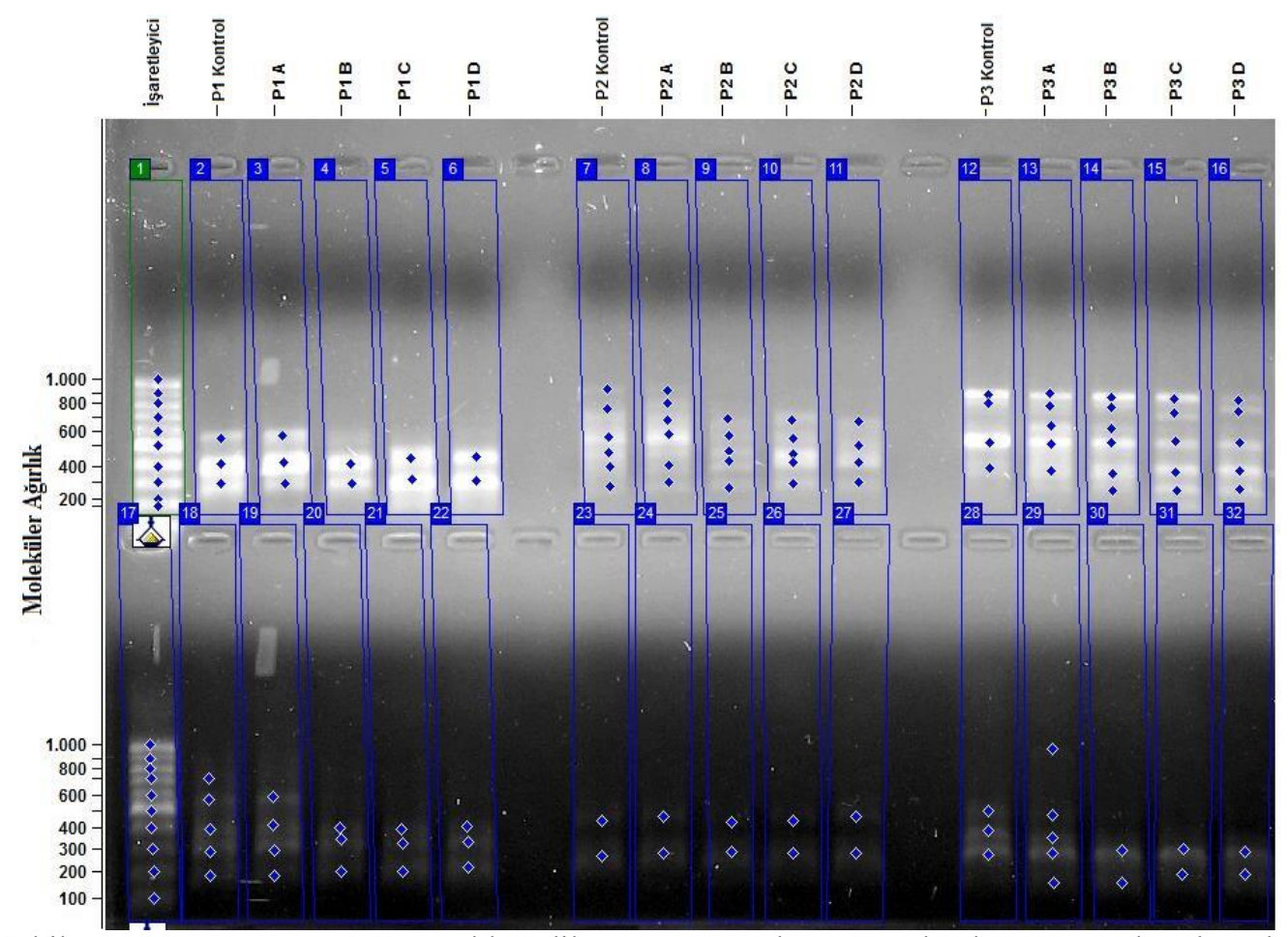

Şekil 1. Satureja hortensis'ten elde edilen uçucu yağların uygulandığı arpa tohumlarından elde edilen DNA örneklerinin OPB-1, OPB-4 , OPB-5, OPB-6, OPB-7, OPB-8 primerlerine karşı gösterdiği amplifikasyon ürünleri ( $\mathrm{P}=$ primer, $\mathrm{A}=1$.doz, $\mathrm{B}=2$. Doz, $\mathrm{C}=3$. Doz, $\mathrm{D}=4$. Doz) 
Uçucu yağlar uygulandıktan sonra çimlendirilen arpa tohumlarının kök örneklerinin olumlu yönde etkilendikleri ya da kontrole göre önemli sayılabilecek oranda büyüdükleri belirlenmiştir. Öte yandan gövde uzunluklarının gelişiminin kontrole göre olumsuz etkilendiği ve bunun dozdan bağımsız bir şekilde gerçekleştiği gözlenmiştir. Bu durumun bitkiden elde edilen bileşenlerin farklılık göstermesinden kaynaklandığı düşünülmektedir. Literatürde bu durumun bazı bileşenlerin sinerjik olarak çalışabileceklerinden kaynaklanabileceği üzerinde yoğunlaşılmıştır (de Oliveira ve ark., 2016). Kelebek larvalarına karşı Timus cinsinden elde edilen uçucu yağların benzer aktivite gösterdikleri (Hummelbrunner ve Isman, 2001) bisabolol ve bornyl acetate gibi bileşenlerin beraber kullanıldıklarında ise antifungal (Kim ve ark., 2016) aktivitelerinin arttığı gözlenmiştir.

İçerik olarak önceki çalışmalarda aynı lokasyonlardan toplanmasına rağmen majör ve minör içeriklerin farklılık gösterdiği gözlenmiştir (Bozarı, 2012). Daha önce \% 78 olarak belirlenen karvakrol bileşiği yakın bölgelerden ancak farklı zaman dilimlerinde toplanan mevcut çalışmada \% 14 oranında tespit edilmiştir. Aynı bölge olmasına rağmen farklı oranlarda içeriklere sahip olması toplanma süresi ile gövde ve yaprak oranlarının farklı olmasından kaynaklanabilir.

RAPD analizleri incelendiğinde uçucu yağların uygulandıkları tohumların genomik stabilitelerini bozduğu gözlenmiştir. Bu durum Satureja hortensis bitkisinin içerdiği Karvakrol, Sitral ve Siklohegzonen (Karvol) türevlerinin neden oldukları etkiden kaynaklanabilir (de Oliveira ve ark., 2016; Azhdarzadeh ve Hojjati, 2016; Thomas ve ark., 2016). $0.8 \mu \mathrm{L} \mathrm{mL} \mathrm{m}^{-1}$ dozunda önemli sayılabilecek oranda polimorfik banda rastlanırken bu durum genomik stabiliteyi \% 53 oranlarında bozmuştur. Bu durum çimlenme oranlarıyla paralellik gösterirken $0.2 \mu \mathrm{L} \mathrm{mL} \mathrm{mL}^{-1}$ dozunda ise tam tersi (\% $72 \mathrm{GTS}$ ve $2.625 \mathrm{~cm}$ çimlenme oranı) bir durum gözlenmiştir. $\mathrm{Bu}$ durum; daha önce de belirtilen farklı içeriklerin sinerjik ya da antogonistik çalışma mekanizmalarıyla açıklanabilir.

Sonuç olarak uçucu yağlar biokontrol amaciyla uygulandıkları bitkilerde çeşitli fizyolojik veya genetik aksaklıklara neden olabilirler. Organizma bu durumdan kurtulmak için farklı protein veya hormonların sentezini gerçekleşebilir veya genom bazında farklı savunma mekanizmalarını çalıştırabilir. Bu etkiye sahip bileşenler, organizmada DNA metil transferaz enzimlerinin aktivitesini etkilemek suretiyle metilasyon veya demetilasyona neden olabilirler (Tollefsbol, 2004). Bundan dolayı mevcut çalışmamızda görülen genomik değişiklikler metilasyonla da açıklanabilir. Her ne kadar çeşitli aksaklıklara neden olsalar bile söz konusu uçucu yağlar doğal olmaları ve nispeten yıkımlarının kolay olması sentetik bileşiklere alternatif olarak kullanılabileceklerini göstermektedir.

\section{TEŞEKKÜR}

$\mathrm{Bu}$ çalışma, Muş Alparslan Üniversitesi BAP Koordinatörlüğü tarafindan MŞÜ14-EMF-G04 nolu projeyle desteklenmiştir. Katkılarından dolayı söz konusu birime teşekkürü borç bilirim.

\section{KAYNAKLAR}

Agar G, Aksakal O, Bozarı S, Sunar S, Erturk FA, Yildirim N, Sevsay S 2010. Genetic variation within and among three populations of Vicia canescens L. (Fabaceae) as revealed by RAPD and FAMEs analysis. Romanian Biotechnological Letters, 15 (4):5384-5391.

Aksakal O, Erturk FA, Sunar S, Bozarı S, Agar G 2013. Assessment of genotoxic effects of 2, 4dichlorophenoxyacetic acid on maize by using RAPD analysis. Industrial Crops and Products, 42:552-557.

Aslan I, Özbek H, Çalmaşur Ö, Şahin F 2004. Toxicity of essential oil vapours to two greenhouse pests, Tetranychus urticae Koch and Bemisia tabaci Genn. Industrial Crops and Products, 19 (2):167-173.

Azhdarzadeh F, Hojjati M 2016. Chemical Composition and Antimicrobial Activity of Leaf, Ripe and Unripe Peel of Bitter Orange (Citrus aurantium) Essential Oils. Nutrition And Food Sciences Research, 3 (1):43-50.

Basile A, Cobianchi RC, Rigano D, Senatore F, Bruno M, Rosselli S, Conte B, Sorbo S 2011. Potential allelopathic activity of Sideritis italica (Miller) Greuter et Burdet essential oil. Plant Biosystems, 145 (1):241-247.

Bozarı S 2012. Lamiaceae Familyasına Ait Farklı Türlerden Elde Edilen Allelopatik Potansiyele Sahip Esansiyel Yağların Genotoksik Etkilerinin Belirlenmesi. Atatürk Universitesi, FBE, Moleküler Biyoloji ABD, Doktora Tezi, 148 s.

Bozarı S, Agar G, Aksakal O, Erturk FA, Yanmis D 2013. Determination of chemical composition and genotoxic effects of essential oil obtained from Nepeta nuda on Zea mays seedlings. Toxicology and Industrial Health, 29 (4):339-348.

Bozarı S, Aksakal O 2013. Application of random amplified polymorphic DNA (RAPD) to detect genotoxic effect of trifluralin on maize ( $\mathrm{Zea}$ mays). Drug and chemical toxicology, 36 (2):163169.

Cenkci S, Yildiz M, Cigerci IH, Konuk M, Bozdag A 2009. Toxic chemicals-induced genotoxicity detected by random amplified polymorphic DNA (RAPD) in bean (Phaseolus vulgaris L.) seedlings. Chemosphere, 76 (7):900-906.

Currie R, Geier P 2016. Weed Control and Crop Injury with Single or Sequential Herbicide Applications in Grain Sorghum. Kansas Agricultural Experiment Station Research Reports, 2 (7):26.

de Oliveira AS, Llanes LC, Brighente IMC, Nunes RJ, Yunes RA, Junior NM, Baumgart AMK, Aust 
AN, Cruz AB 2016. New Sulfonamides Derived from Carvacrol: Compounds with High Antibacterial Activity against Resistant Staphylococcus aureus Strains. Journal of Biosciences and Medicines, 4 (7):105-114.

Facchini PJ 2001. Alkaloid biosynthesis in plants: biochemistry, cell biology, molecular regulation, and metabolic engineering applications. Annual Review of Plant Biology, 52 (1):29-66.

Gkinis G, Bozin B, Mimica-Dukic N, Tzakou O 2010. Antioxidant Activity of Nepeta nuda L. ssp. nuda Essential Oil Rich in Nepetalactones from Greece. Journal of Medicinal Food, 13 (5):1176-1181.

Gormez A, Bozarı S, Yanmis D, Gulluce M, Agar G, Sahin F 2016. The Use of Essential Oils of Origanum rotundifolium as Antimicrobial Agent Against Plant Pathogenic Bacteria. Journal of Essential Oil Bearing Plants, 19 (3):656-663.

Gulluce M, Sahin F, Sokmen M, Ozer H, Daferera D, Sokmen A, Polissiou M, Adiguzel A, Ozkan H 2007. Antimicrobial and antioxidant properties of the essential oils and methanol extract from Mentha longifolia L. ssp. longifolia. Food Chemistry, 103 (4):1449-1456.

Güllüce M, Sökmen M, Daferera D, Agar G, Özkan H, Kartal N, Polissiou M, Sökmen A, Sahin F 2003. In vitro antibacterial, antifungal, and antioxidant activities of the essential oil and methanol extracts of herbal parts and callus cultures of Satureja hortensis L. Journal of Agricultural and food chemistry, 51 (14):3958-3965

Güney CO, Özkan K, Şentürk Ö 2016. Modelling of spatial prediction of fire ignition risk in the Antalya-Manavgat district. Journal of the Faculty of Forestry Istanbul University,, 66 (2):459-470.

Hajhashemi V, Ghannadi A, Pezeshkian SK 2002. Antinociceptive and anti-inflammatory effects of Satureja hortensis L. extracts and essential oil. Journal of Ethnopharmacology, 82 (2):83-87.

Hartmann $T$ 2007. From waste products to ecochemicals: Fifty years research of plant secondary metabolism. Phytochemistry, 68 (2224):2831-2846.

Hummelbrunner LA, Isman MB 2001. Acute, sublethal, antifeedant, and synergistic effects of monoterpenoid essential oil compounds on the tobacco cutworm, Spodoptera litura (Lep., Noctuidae). Journal of Agricultural and Food Chemistry, 49 (2):715-720.

Katar D, Arslan Y, Subaşı İ, Bülbül A 2011. Ankara Ekolojik Koşullarında Sater (Satureja hortensis L.) Bitkisinde Uçucu Yağ ve Bileşenlerinin Ontogenetik Varyabilitesinin Belirlenmesi. Tekirdağ Ziraat Fakültesi Dergisi, 8 (2):29-36.

Kim SH, Lee SY, Cho SM, Hong CY, Park MJ, Choi IG 2016. Evaluation on Anti-fungal Activity and Synergy Effects of Essential Oil and Their Constituents from Abies holophylla. Journal of the Korean Wood Science and Technology, 44 (1):113-123.
Kim SI, Yoon JS, Jung JW, Hong KB, Ahn YJ, Kwon HW 2010. Toxicity and repellency of origanum essential oil and its components against Tribolium castaneum (Coleoptera: Tenebrionidae) adults. Journal of Asia-Pacific Entomology, 13 (4):369-373.

Kobayashi K, Itaya D, Mahatamnuchoke P, Pornprom T 2008. Allelopathic potential of itchgrass (Rottboellia exaltata L.) powder incorporated into soil. Weed Biology and Management, 8 (1):64-68.

Liebman M, Dyck E 1993. Crop rotation and intercropping strategies for weed management. Ecological applications, 3 (1):92-122.

Maede M, Hamzeh I, Hossein D, Majid A, Reza RK 2013. Bioactivity of essential oil from Satureja hortensis (Laminaceae) against three storedproduct insect species. African Journal of Biotechnology, 10 (34):6620-6627.

Milun V, Grgas D, Dragičević TL 2016. Assessment of PCB and chlorinated pesticide accumulation in mussels at Kaštela Bay (Eastern Adriatic). Science of the Total Environment, 562:115-127.

Mossa ATH 2016. Green Pesticides: Essential Oils as Biopesticides in Insect-pest Management. Journal of Environmental Science and Technology, 9 (5):354.

Mutlu S, Atici O 2009. Allelopathic effect of Nepeta meyeri Benth. extracts on seed germination and seedling growth of some crop plants. Acta Physiologiae Plantarum, 31 (1):89-93.

Nguyen TT, Berg H, Van Nguyen C 2016. The joint toxicity effects of Chlorpyrifos ethyl and Fenobucarb to Climbing perch (Anabas testudineus) from rice fields in the Mekong Delta, Vietnam.

Nicot PC, Stewart A, Bardin M, Elad Y 2016. Biological Control and Biopesticide Suppression of Botrytis-Incited Diseases. Springer, 165-187 s.

Ntalli NG, Ferrari F, Giannakou I, MenkissogluSpiroudi U 2010. Phytochemistry and nematicidal activity of the essential oils from 8 Greek Lamiaceae aromatic plants and 13 terpene components. Journal of Agricultural and Food Chemistry, 58 (13):7856-7863.

Sahai P 2016. Determination of Some Pesticide Residues in Cauliflower (Brassica oleracea var botrytis) by High Performance Liquid Chromatography. International Journal of Ecology and Environmental Sciences, 42 (1): 3537.

Shafaghat A 2011. Antioxidant, antimicrobial activities and fatty acid components of leaf and seed of Bupleurum lancifolium Hornem. Journal of Medicinal Plants Research, 5 (16):3758-3762.

Singh H, Batish DR, Kohli R 2003. Allelopathic interactions and allelochemicals: new possibilities for sustainable weed management. Critical reviews in plant sciences, 22 (3-4):239-311. 
Sodaeizadeh H, Hosseini Z 2012. Allelopathy an environmentally friendly method for weed control. International Conference on Applied Life Sciences.10-12 September, Turkey.

Şahin F, Karaman I, Güllüce M, Öğütçü H, Şengül M, Adigüzel A, Öztürk S, Kotan R 2003. Evaluation of antimicrobial activities of Satureja hortensis L. Journal of Ethnopharmacology, 87 (1):61-65.

Thomas ML, De Antueno R, Coyle K, Cruickshank B, Giacomantonio M, Duncan R, Giacomantonio C, Marcato P 2016. Citral reduces breast tumor growth by inhibiting cancer stem cell marker ALDH1A3. Cancer Research, $76 \quad$ (14 Supplement):2506-2506.

Tokatlı C, Emiroğlu Ö, Arslan N, Köse E, Çiçek A, Dayığlu H, Başkurt S 2016. Maden Havzası Balıklarında Vücut Ağırlığı ile Ağır Metal Biyoakümülasyon İlişkileri: Emet Çayı Havzası. Anadolu University Journal of Science and Technology-C Life Sciences and Biotechnology, 4 (2):57-72.
Tollefsbol TO 2004. Epigenetics protocols. Humana Pr Inc, Vol. 287s.

Tworkoski T 2002. Herbicide effects of essential oils. Weed Science, 50(4): 425-431.

Villaverde JJ, Sandín-España P, Sevilla-Morán B, López-Goti C, Alonso-Prados JL 2016. Biopesticides from Natural Products: Current Development, Legislative Framework, and Future Trends. BioResources, 11 (2):5618-5640.

Wang Y, An X, Shen W, Chen L, Jiang J, Wang Q, Cai L 2016. Individual and combined toxic effects of herbicide atrazine and three insecticides on the earthworm, Eisenia fetida. Ecotoxicology, 25 (5):991-999.

Wink M 2010. Functions and biotechnology of plant secondary metabolites. Blackwell Pub, 72s.

Yarsan E, Çevik A 2007. Vektör Mücadelesinde Biyopestisitler. Türk Hijyen ve Deneysel biyoloji Dergisi, 64(1):61-70. 